IZA DP No. 8563

Performance Pay, Competitiveness, and the Gender Wage Gap:

Evidence from the United States

Andrew McGee

Peter McGee

Jessica Pan

October 2014 


\title{
Performance Pay, Competitiveness, and the Gender Wage Gap: Evidence from the United States
}

\author{
Andrew McGee \\ Simon Fraser University \\ and IZA \\ Peter McGee \\ National University of Singapore \\ Jessica Pan \\ National University of Singapore
}

Discussion Paper No. 8563

October 2014

\author{
IZA \\ P.O. Box 7240 \\ 53072 Bonn \\ Germany \\ Phone: +49-228-3894-0 \\ Fax: +49-228-3894-180 \\ E-mail: iza@iza.org
}

\begin{abstract}
Any opinions expressed here are those of the author(s) and not those of IZA. Research published in this series may include views on policy, but the institute itself takes no institutional policy positions. The IZA research network is committed to the IZA Guiding Principles of Research Integrity.

The Institute for the Study of Labor (IZA) in Bonn is a local and virtual international research center and a place of communication between science, politics and business. IZA is an independent nonprofit organization supported by Deutsche Post Foundation. The center is associated with the University of Bonn and offers a stimulating research environment through its international network, workshops and conferences, data service, project support, research visits and doctoral program. IZA engages in (i) original and internationally competitive research in all fields of labor economics, (ii) development of policy concepts, and (iii) dissemination of research results and concepts to the interested public.
\end{abstract}

IZA Discussion Papers often represent preliminary work and are circulated to encourage discussion. Citation of such a paper should account for its provisional character. A revised version may be available directly from the author. 
IZA Discussion Paper No. 8563

October 2014

\section{ABSTRACT \\ Performance Pay, Competitiveness, and the Gender Wage Gap: Evidence from the United States}

Evidence that women are less likely to opt into competitive compensation schemes in the laboratory has generated speculation that a gender difference in competitiveness contributes to the gender wage gap. Using data from the NLSY79 and NLSY97, we show that women are less likely to be employed in jobs using competitive compensation. The portion of the gender wage gap explained by gender segregation in compensation schemes is small in the NLSY79 but somewhat larger in the NLSY97 - suggesting an increasing role for competitiveness in explaining the gender wage gap.

JEL Classification: J16, A12

Keywords: $\quad$ gender wage gap, competitiveness, performance pay

Corresponding author:

Andrew McGee

Department of Economics

Simon Fraser University

8888 University Drive

Burnaby, BC V5A 156

Canada

E-mail: andrew_mcgee@sfu.ca 


\section{Introduction}

Laboratory findings that women are less likely than men to opt into competitive environments have led to speculation that a gender difference in competitiveness contributes to the gender wage gap (Gneezy et al. 2003, Niederle and Vesterlund 2007). While differences in attitudes toward competition may influence labor market outcomes through their effects on educational and occupational choices (Kleinjans 2009, Buser et al. 2014), there is little evidence that a gender difference in preferences concerning participation in competitive compensation schemes contributes to the gender wage gap.

In an attempt to examine the relevance of competitiveness to the gender wage gap, Manning and Saidi (2010) use an indicator for whether a worker's compensation is based, in part, on performance to proxy for a job's competitiveness as the pay on such jobs is typically determined by relative performance across workers. They find that women in the United Kingdom are only slightly less likely than men to be employed in jobs in which compensation is based on performance, and gender differences in the receipt of performance pay explain only a small portion of the gender wage gap in their data. Given that the experimental literature on competitiveness finds large gender differences in preferences over participation in competitive pay schemes, their findings cast doubt on the importance of gender differences in competitiveness in the labor market.

Using data from the National Longitudinal Surveys of Youth (NLSY) 1979 and 1997 cohorts, we examine whether women in the United States are less likely to receive compensation determined by their performance in competition with their peers and whether gender segregation in the receipt of performance pay explains any of the gender wage gap in the United States. Consistent with the laboratory studies, we find that women are less likely to be employed in jobs using the most competitive forms of performance pay (commissions and bonuses), but this gender difference is nowhere near as large as the analogous gender difference observed in the laboratory. When we include measures of performance pay in standard gender wage regressions, we find that the receipt of performance pay explains a small but possibly increasing portion of the gender wage gap in the United States.

\section{Data}

The data come from the NLSY79 and NLSY97 cohorts. Respondents in the NLSY79 were asked whether their earnings were based on job performance in 1988, 1989, 1990, 1996, 1998, and 2000. If their earnings were based in part on job performance, they indicated the type of performance pay (piece-rates, tips, commissions, bonuses, stock options and other performance pay). Respondents in the NLSY97 were asked in all survey years (1997-2011) the types of compensation they received (overtime, tips, commissions, bonuses, incentive pay, and other compensation) in addition to their base pay. For both cohorts and using data from the years in which compensation types are available, we construct an indicator from these responses for whether performance pay was received (excluding overtime for the NLSY97).

Table 1 details the summary statistics for the samples. Workers of both genders in both cohorts receiving performance pay have higher wages than workers not receiving performance pay. In 
the NLSY79, men are nearly five percentage points more likely to receive performance pay than women, but there is substantial heterogeneity in the type of performance pay received. Women are more likely to be working for tips but substantially less likely to be earning commissions, bonuses, and stock options. Women in the NLSY97 are actually slightly more likely to be working for performance pay - the definition of which is not strictly comparable to that in the NLSY79 due to survey differences - than their male peers, but this is driven by the fact that many women in this younger cohort are working for tips. As in the NLSY79, women in the NLSY97 are also less likely to be working for commissions and bonuses. Because commissions and bonuses are often won at the expense of other employees when sales cannot be shared and the bonus pool is fixed, we consider them to be more competitive forms of compensation than tips and other types of performance pay, and we separately analyze the receipt of the different types of performance pay and their effects on the gender wage gap in the next section. By contrast, Manning and Saidi (2010) disaggregate their performance pay measure by looking at gender differences in merit pay, piece-rates, and individual-based performance pay, but it is unclear a priori which of these compensation schemes is most competitive.

Table 1 also details the summary statistics for the controls used in the next section, which were chosen to match those used in Manning and Saidi (2010) as closely as possible. The only difference in the controls used in our studies is that the Manning and Saidi study incorporates firm effects, which is impossible in the NLSY. The inclusion of firm effects, however, appears to have had little influence on their findings, which we discuss below.

\section{Findings}

Table 2 reports the estimated marginal effects of being female on the probability of receiving different types of performance pay in various specifications of a probit model for both samples. Compared to Manning and Saidi (2010) who find that women are 1.2 percentage points less likely to receive performance pay conditional on personal characteristics, job characteristics, and occupation, women in the NLSY79 are 2.3 percentage points less likely to be working for performance pay than their male peers in a similar specification. Women in the NLSY97 are no less likely than men to be working for performance pay, but again this difference between cohorts is driven by differences in the definition of performance pay and the fact that young women are more likely than their young male peers and older workers to be working for tips.

Indeed, we see more similarities than differences across the cohorts in the female marginal effects when we examine well-defined performance pay-types controlling for personal characteristics, job characteristics and occupation. Women in the NLSY79 (NLSY97) are 1.5 (1.6) and 3.7 (1.8) percentage points less likely to be receiving compensation through commissions and bonuses, respectively, than their male peers, but 0.9 (2.8) percentage points more likely to be working for tips. Thus in both cohorts women are less likely to be working for the more competitive forms of performance pay-though as in Manning and Saidi (2010) this difference is not particularly large.

Manning and Saidi (2010) estimate that the contribution of performance pay to the gender wage gap is approximately half of one percentage point. To examine whether the gender differences in the receipt of competitive performance pay in table 2 translate into gender differences in wages, 
table 3 reports the gender wage gap in our samples in specifications with and without each performance pay indicator. For the NLSY79, the performance pay indicator explains a small but non-zero portion of the unconditional gender wage gap. Controlling for personal and job characteristics and occupation, the receipt of performance pay explains 1.2 percent of the gender wage gap. For the NLSY97, controlling for performance pay actually results in a larger gender wage gap as performance pay is positively related to wages and women are more likely to receive performance pay (mainly tips).

Again though, the dissimilarity between the cohorts is primarily the result of aggregating different pay types. In both cohorts, the receipt of the most competitive forms of compensation explains a non-trivial portion of the gender wage gap. In the NLSY79 (NLSY97), the receipt of commissions and/or bonuses explains 3.6 (13.8) percent of the gender wage gap. If workers sort into jobs based on their preferences for competing with others, then the evidence in table 3 indicates that competitiveness explains a similar (larger) fraction of the gender wage gap in the United States in the NLSY79 (NLSY97) relative to what Manning and Saidi (2010) found in the United Kingdom. ${ }^{1}$ That the contribution of the receipt of competitive compensation to the gender wage gap is larger in the more recent cohort may reflect the increasing fraction of jobs using performance pay and the fact that earnings from performance pay are more closely tied to observed and unobserved worker productivity than earnings from other forms of compensation (Lemieux et al. 2009). As a consequence of their higher propensity to work on jobs using competitive performance pay, men may have disproportionately benefited from the welldocumented increase in the returns to skill (Juhn et al. 1993).

\section{Discussion}

In the laboratory, Niederle and Vesterlund (2007) and Dargnies (2012) find that women are 38 and 33 percentage points, respectively, less likely to opt into competitive tournaments than their male peers - electing to work for piece-rates instead. In the NLSY cohorts, we observe significantly less gender segregation in the receipt of competitive performance pay in the labor market than in the lab, and this gender difference accounts for a small portion of the gender wage gap. Questions for future research naturally follow. First, why is there a large difference in the importance of competitiveness in the laboratory and the labor market? One possibility is that while in the lab subjects choose between environments fully characterized by differences in competitiveness, in real life workers choose between jobs with many characteristics. A variety of different preferences over work conditions may be involved. Competitiveness may not be the most important preference where gender differences in the labor market are concerned, and further investigation of gender differences in preferences over work conditions seems warranted. Second, is performance pay a good proxy for the competitiveness of a job? While competition in the laboratory can be defined by compensation schemes, workers in many jobs compete for the next job, for the terms of the next contract, or for limited work opportunities. Indeed, the correlation between the receipt of performance pay and how competitive workers in an

\footnotetext{
${ }^{1}$ We may understate the degree to which women opt out of competitive environments if workers sort based on their competitiveness when choosing occupations and industries. For both tables 2 and 3, however, we obtain similar estimates when we exclude industry and occupation from the controls (estimates available from the authors).
} 
occupation say their job is as measured in Occupational Information Network (O*NET) data is only $0.18(0.14)$ in our NLSY79 (NLSY97) sample. If performance pay is a poor proxy for the degree of competition on a job, then our findings and those of Manning and Saidi (2010) may dramatically understate the importance of competitiveness in the explaining the gender wage gap. Finally, in the labor market women may be constrained in the ability to compete by domestic responsibilities given that highly competitive jobs may require long hours and other sacrifices (Goldin 2014). Future research must take care not to conflate gender differences in the ability to compete in the labor market with gender differences in preferences for competition. 


\section{References}

Buser, T., Niederle, M., and Oosterbeek, H. 2014. "Gender, Competitiveness, and Career Choices.” Quarterly Journal of Economics, 129(3), pp. 1409-1447.

Dargnies, M. 2012. "Men, too, Sometimes Shy Away from Competition: The Case of Team Competition.” Management Science, 58 (11), pp. 1982-2000.

Goldin C. 2014. "A Grand Gender Convergence: Its Last Chapter." American Economic Review, 104 (4), pp.1091-1119.

Gneezy, U., Niederle, M., and Rustichini, A. 2003. "Performance in Competitive Environments: Gender Differences.” Quarterly Journal of Economics, 118 (3), pp. 1049-1074.

Juhn, C., Murphy, K. and Pierce, B. 1993. "Wage Inequality and the Rise in Returns to Skill." Journal of Political Economy, 101, pp. 410-442.

Kleinjans, K. 2009. "Do Gender Differences in Preferences for Competition Matter for Occupational Expectations?” Journal of Economic Psychology, 30, pp. 701-710.

Lemieux, T., MacLeod, B., and Parent, D. 2009. "Performance Pay and Wage Inequality." Quarterly Journal of Economics, 124 (1), pp. 1-49.

Manning, A. and Saidi, F. 2010. "Understanding the Gender Pay Gap: What's Competition Got to Do with It?” Industrial and Labor Relations Review, 63 (4), pp. 681-698.

Niederle, M. and Vesterlund, L. 2007. "Do Women Shy Away from Competition? Do Men Compete Too Much?" Quarterly Journal of Economics, 122 (3), pp. 1067-1101. 
Table 1: Summary statistics for the estimation samples

\begin{tabular}{|c|c|c|c|c|c|c|c|c|c|c|c|c|}
\hline \multirow[b]{3}{*}{ Variable } & \multicolumn{6}{|c|}{ NLSY79 sample } & \multicolumn{6}{|c|}{ NLSY97 sample } \\
\hline & \multirow[b]{2}{*}{ All } & \multicolumn{2}{|c|}{$\begin{array}{l}\text { Men } \\
\text { Performance pay? }\end{array}$} & \multicolumn{3}{|c|}{$\begin{array}{l}\text { Women } \\
\text { Performance pay? }\end{array}$} & \multicolumn{4}{|c|}{$\begin{array}{l}\text { Men } \\
\text { Performance pay? }\end{array}$} & \multicolumn{2}{|c|}{$\begin{array}{l}\text { Women } \\
\text { Performance pay? }\end{array}$} \\
\hline & & No & Yes & All & No & Yes & All & No & Yes & All & No & Yes \\
\hline Performance pay & 0.245 & & & 0.196 & & & 0.217 & & & 0.225 & & \\
\hline Tips & 0.020 & & 0.080 & 0.035 & & 0.179 & 0.051 & & 0.233 & 0.081 & & 0.358 \\
\hline Commissions & 0.049 & & 0.198 & 0.029 & & 0.146 & 0.045 & & 0.206 & 0.038 & & 0.171 \\
\hline Bonuses & 0.151 & & 0.612 & 0.109 & & 0.550 & 0.123 & & 0.565 & 0.101 & & 0.451 \\
\hline Stock options & 0.026 & & 0.105 & 0.014 & & 0.069 & & & & & & \\
\hline Piece-rate & 0.027 & & 0.111 & 0.024 & & 0.118 & & & & & & \\
\hline Other performance pay & 0.027 & & 0.108 & 0.020 & & 0.099 & & & & & & \\
\hline Incentive pay & & & & & & & 0.028 & & 0.131 & 0.028 & & 0.124 \\
\hline Other compensation & & & & & & & 0.004 & & 0.018 & 0.004 & & 0.020 \\
\hline \multirow[t]{2}{*}{ Log-hourly wage } & 2.533 & 2.495 & 2.648 & 2.337 & 2.331 & 2.363 & 2.417 & 2.340 & 2.696 & 2.311 & 2.234 & 2.576 \\
\hline & {$[0.615]$} & {$[0.594]$} & {$[0.664]$} & {$[0.598]$} & {$[0.582]$} & {$[0.659]$} & {$[0.612]$} & {$[0.572]$} & {$[0.667]$} & {$[0.550]$} & {$[0.499]$} & {$[0.627]$} \\
\hline High school graduate & 0.460 & 0.479 & 0.401 & 0.433 & 0.432 & 0.438 & 0.394 & 0.408 & 0.341 & 0.333 & 0.342 & 0.303 \\
\hline Some college & 0.192 & 0.189 & 0.199 & 0.260 & 0.261 & 0.257 & 0.217 & 0.211 & 0.240 & 0.240 & 0.230 & 0.275 \\
\hline College/graduate degree & 0.194 & 0.169 & 0.272 & 0.220 & 0.223 & 0.207 & 0.194 & 0.173 & 0.267 & 0.289 & 0.289 & 0.291 \\
\hline Black & 0.261 & 0.273 & 0.224 & 0.272 & 0.281 & 0.236 & 0.211 & 0.212 & 0.206 & 0.245 & 0.261 & 0.189 \\
\hline Hispanic & 0.180 & 0.182 & 0.175 & 0.168 & 0.169 & 0.162 & 0.231 & 0.236 & 0.215 & 0.219 & 0.226 & 0.194 \\
\hline \multirow{2}{*}{$\begin{array}{l}\text { Work experience } \\
\text { (years) }\end{array}$} & 11.962 & 11.849 & 12.312 & 11.138 & 11.122 & 11.203 & 6.753 & 6.565 & 7.430 & 6.712 & 6.557 & 7.247 \\
\hline & {$[5.087]$} & {$[5.080]$} & {$[5.093]$} & {$[5.128]$} & {$[5.136]$} & {$[5.095]$} & [3.342] & [3.343] & [3.248] & {$[3.250]$} & {$[3.253]$} & [3.183] \\
\hline \multirow[t]{2}{*}{ Tenure (weeks) } & 232.16 & 234.08 & 226.25 & 225.21 & 227.30 & 216.64 & 127.97 & 123.90 & 142.61 & 122.78 & 119.72 & 133.36 \\
\hline & {$[236.78]$} & [238.59] & {$[231.05]$} & [231.15] & {$[232.86]$} & {$[223.85]$} & [116.59] & {$[115.76]$} & [118.40] & {$[110.20]$} & [108.64] & [114.80] \\
\hline Married & 0.555 & 0.551 & 0.566 & 0.552 & 0.556 & 0.535 & 0.231 & 0.226 & 0.249 & 0.288 & 0.283 & 0.304 \\
\hline Has children & 0.490 & 0.492 & 0.485 & 0.650 & 0.661 & 0.607 & 0.322 & 0.332 & 0.287 & 0.433 & 0.439 & 0.410 \\
\hline \multirow{2}{*}{$\begin{array}{l}\text { Log number of } \\
\text { employees }\end{array}$} & 4.079 & 4.106 & 3.995 & 4.260 & 4.298 & 4.103 & 3.629 & 3.588 & 3.776 & 3.656 & 3.658 & 3.646 \\
\hline & {$[2.237]$} & {$[2.234]$} & {$[2.245]$} & {$[2.231]$} & [2.231] & {$[2.221]$} & {$[1.920]$} & [1.926] & [1.892] & {$[1.890]$} & [1.916] & {$[1.798]$} \\
\hline Government sector & 0.124 & 0.152 & 0.038 & 0.176 & 0.204 & 0.063 & 0.081 & 0.096 & 0.028 & 0.117 & 0.141 & 0.036 \\
\hline Union or CBA & 0.220 & 0.245 & 0.140 & 0.177 & 0.190 & 0.121 & 0.138 & 0.154 & 0.080 & 0.108 & 0.125 & 0.047 \\
\hline
\end{tabular}

Note: Standard deviations in brackets. There are 18,199 (15,629) person-year observations for men (women) in the NLSY79, and 15,395 (14,548) person-year observations for men (women) in the NLSY97. Wages were deflated to 1998 dollars using the CPI for urban consumers before taking logs. In both samples, observations were restricted to workers over age 18 who were working and not enrolled in school in the week of their interview and who had no missing values for the variables in the table above as well as the industry and occupation of the respondent's job. 
Table 2: Probit estimates of marginal effect of being female on whether performance pay received

\begin{tabular}{|c|c|c|c|c|c|}
\hline \multirow[b]{2}{*}{ Dependent variable } & \multicolumn{2}{|c|}{ Female marginal effect } & \multirow[b]{2}{*}{$\begin{array}{l}\text { Personal } \\
\text { characteristics }\end{array}$} & \multirow[b]{2}{*}{$\begin{array}{l}\text { Job } \\
\text { characteristics }\end{array}$} & \multirow[b]{2}{*}{$\begin{array}{l}\text { Occupation } \\
\text { dummies }\end{array}$} \\
\hline & NLSY79 & NLSY97 & & & \\
\hline Performance pay & $\begin{array}{l}-0.049 \\
{[0.006]}\end{array}$ & $\begin{array}{l}0.007 \\
{[0.008]}\end{array}$ & No & No & No \\
\hline Performance pay & $\begin{array}{l}-0.048 \\
{[0.007]}\end{array}$ & $\begin{array}{l}0.009 \\
{[0.008]}\end{array}$ & Yes & No & No \\
\hline Performance pay & $\begin{array}{l}-0.034 \\
{[0.007]}\end{array}$ & $\begin{array}{l}0.010 \\
{[0.008]}\end{array}$ & Yes & Yes & No \\
\hline Performance pay & $\begin{array}{l}-0.023 \\
{[0.007]}\end{array}$ & $\begin{array}{l}0.009 \\
{[0.008]}\end{array}$ & Yes & Yes & Yes \\
\hline Tips & $\begin{array}{l}0.009 \\
{[0.002]}\end{array}$ & $\begin{array}{l}0.028 \\
{[0.004]}\end{array}$ & Yes & Yes & Yes \\
\hline Commissions & $\begin{array}{l}-0.015 \\
{[0.003]}\end{array}$ & $\begin{array}{l}-0.016 \\
{[0.004]}\end{array}$ & Yes & Yes & Yes \\
\hline Bonuses & $\begin{array}{l}-0.037 \\
{[0.005]}\end{array}$ & $\begin{array}{l}-0.018 \\
{[0.005]}\end{array}$ & Yes & Yes & Yes \\
\hline Stock options & $\begin{array}{l}-0.008 \\
{[0.002]}\end{array}$ & & Yes & Yes & Yes \\
\hline Piece-rate & $\begin{array}{l}0.011 \\
{[0.003]}\end{array}$ & & Yes & Yes & Yes \\
\hline Other performance pay & $\begin{array}{l}-0.006 \\
{[0.002]}\end{array}$ & & Yes & Yes & Yes \\
\hline Incentive pay & & $\begin{array}{l}-0.0002 \\
{[0.003]}\end{array}$ & Yes & Yes & Yes \\
\hline Other compensation & & $\begin{array}{l}0.0002 \\
{[0.001]}\end{array}$ & Yes & Yes & Yes \\
\hline
\end{tabular}

Note: The sample sizes are 33,828 and 29,943 for the NLSY79 and NLSY97, respectively. The standard errors reported in brackets are robust to heteroskedasticity at the respondent level. The dependent variable in the first four rows is an indicator for whether a respondent's compensation includes any performance pay. Performance pay includes tips, commissions, bonuses, stock options, piece-rates, and other performance pay in the NLSY79, while in the NLSY97 performance pay includes tips, commissions, bonuses, incentive pay, and other compensation. The dependent variables in the remaining rows are indicators for whether the respondent's compensation includes the particular performance pay-type associated with the row. Personal characteristics include education, race, experience, tenure, marital status, and whether the respondent has children. Job characteristics include industry, the $\log$ of the number of employees at a respondent's job, whether the job is in government, and whether the worker's contract is determined by a union or collective bargaining agreement. 
Table 3: Estimated relationships between performance pay types and the gender wage gap

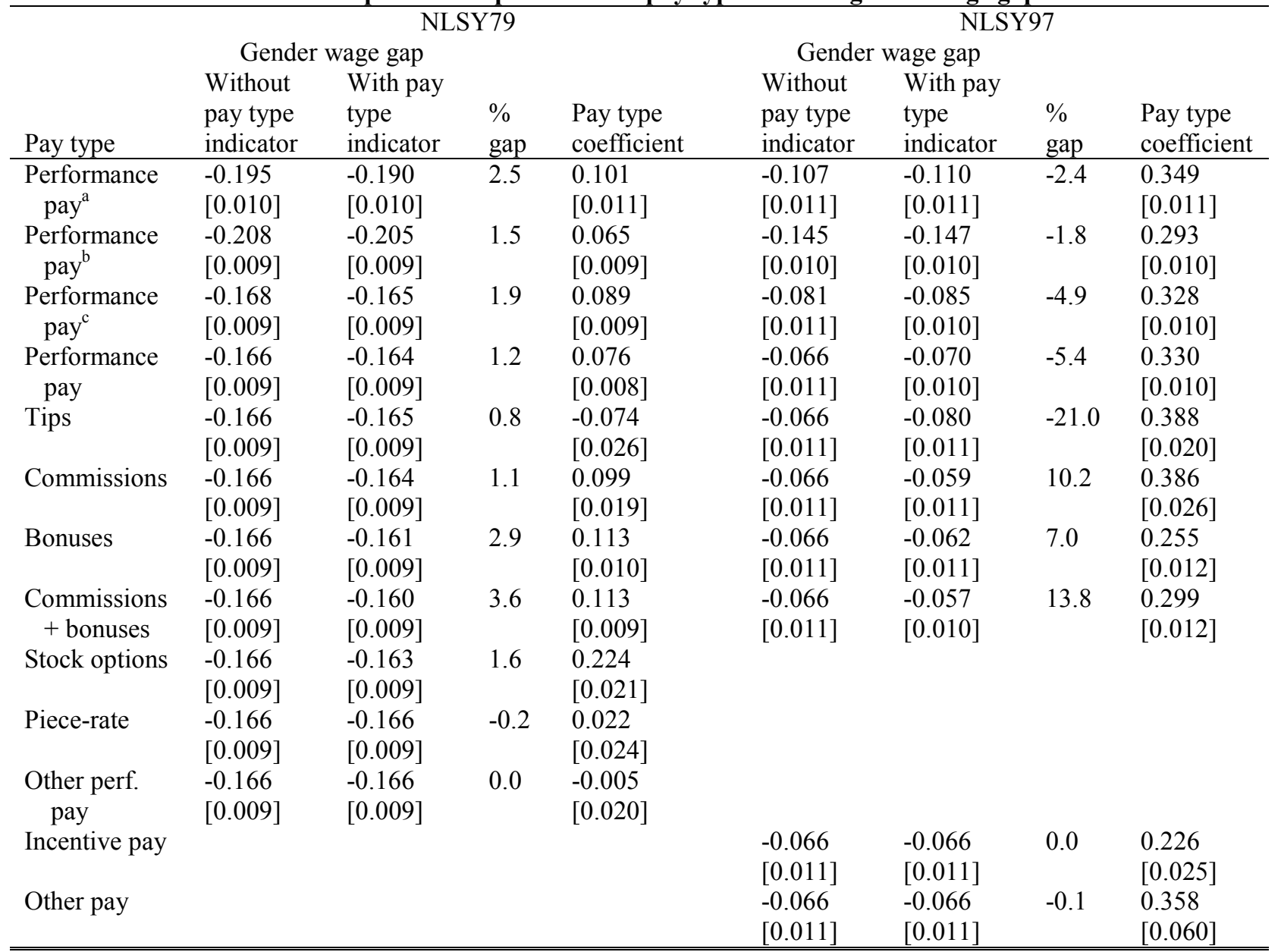

a - No control variables.

b - Personal controls only.

c - Personal and job controls only.

Note: The sample sizes are 33,828 and 29,943 for the NLSY79 and NLSY97, respectively. The standard errors reported in brackets are robust to heteroskedasticity at the respondent level. Except where otherwise noted, the controls include personal and job characteristics and occupation dummies. The column " $\%$ gap" refers to the percent change in the estimated gender wage gap with the inclusion of the pay-type indicator. 